\title{
Pemanfaatan Terapi Tradisional dan Alternatif oleh Penderita Gangguan Jiwa
}

\author{
Muhammad Arsyad Subu \\ Sekolah Tinggi Ilmu Kesehatan Binawan \\ Email:msubu061@uottawa.ca
}

\begin{abstract}
Abstrak
Sampai saat ini masih sedikit informasi dari hasil-hasil penelitian tentang pemanfaatan terapi tradisional dan alternatif oleh para penderita gangguan jiwa di Indonesia. Penelitian ini bertujuan untuk melihat bagaimana pemanfaatan terapi tradisional dan alternatif di antara penderita gangguan jiwa di Indonesia. Metode penelitian ini menggunakan Charmaz Constructive Grounded Theory untuk mengeksplorasi pemanfaatan terapi tradisional dan alternatif di antara pasien yang menderita gangguan jiwa. Metode pengumpulan data termasuk interaksi langsung (wawancara semi-terstruktur), document review, catatan lapangan dan memo. Data analisis menggunakan pendekatan Paille data analisis. Penelitian menghasilkan lima kategori: 1) kerasukan oleh setan atau roh; 2) penyakit akibat berdosa; 3) Berobat ke tradisional dulu baru akhirnya ke rumah sakit jiwa; 4) kekerasan; 5) takut dengan pengobatan. Hasil penelitian menunjukkan bahwa terapi tradisional dan alternatif dan orang pintar (dukun, para pemimpin agama Islam, pendeta, paranormal dan pengobatan tradisional Cina) memiliki peran sentral dalam mendukung dan menawarkan solusi ketika seseorang memiliki gangguan jiwa di Indonesia. Para terapis atau 'orang pintar' biasanya merupakan pilihan pertama dari keluarga dan anggota 'masyarakat lainnya jika berhubungan dengan terapi yang orang yang menderita gangguan jiwa. Penelitian lanjut diperlukan untuk melihat efektivitas terapi tradisional dan alternatif ini yang masih kurang diteliti dan didokumentasikan di Indonesia. Penelitian lebih lanjut juga perlu dilakukan untuk memahami sikap atau perspektif keluarga, masyarakat dan staf lembaga pemerintahan sebagai partisipan terkait dengan pengobatan tradisional dan alternatif ini. Penelitian ini menggunakan pendekatan kualitatif, penelitian kuantitatif diperlukan untuk meneliti faktor-faktor yang mempengaruhi pemanfaaatan terapi tradisional dan alternatif oleh penderita gangguan jiwa di Indonesia.
\end{abstract}

Kata kunci: Gangguan jiwa, terapi, tradisional-alternatif.

\section{Traditional and Alternative Therapies Usage by Psychiatric Patients: A Grounded Theory.}

\begin{abstract}
Until recently, little information is known from studies regarding the use of traditional and alternative therapies by people with mental illness in Indonesia. This study explored the use of traditional or alternative therapies among mentally ill sufferers in Indonesia. A Charmaz's Constructivist Grounded Theory method was used to explore the use of traditional or alternative therapies among patients as a result of suffering from mental illness. Data collection method involved direct interaction (semi-structured interviews), mute evidence (document review), field notes and memos. Paillé (1994) data analysis was employed to organize and manage data. Study has led to five categories: 1) possessed by Satan or spirit; 2) sinful illness; 3) treatment at traditional before going to the hospital; 4) violence; 5) fear of treatment. Study results indicated that complementary - alternative treatments and 'smart people' (shamans, Islamic leaders, chaplains, paranormal and traditional Chinese medicine) have a central role in supporting and offering solutions when someone has a mental illness in Indonesia. Visiting therapists or 'smart people', is usually the first choice of patients, families and other community members when dealing with the mentally ill treatments. Further research is needed to see the effectiveness of traditional or alternative therapy which is still poorly researched and documented in Indonesia. It is also needed to understand the attitude or perspective of the family, the community and government staff as participants regarding traditional or alternative therapies. This study used a qualitative approach, thus quantitative research is needed to examine the factors that affect the utilization of traditional or alternative therapies by mentally ill people in Indonesia..
\end{abstract}

Key words: Alternative, mental illness, therapy, traditional. 
Muhammad Arsyad Subu: Pemanfaatan Terapi Tradisional dan Alternatif

\section{Pendahuluan}

Istilah 'penyakit jiwa' digunakan untuk menunjukkan berbagai masalah dan perilaku akibat gangguan jiwa yang termasuk dalam the International Statistical Classification of Diseases and Related Health Problems, Tenth revision (ICD-10) (WHO, 2013). Penyakit gangguan jiwa termasuk "gangguan atau penyakit seperti depresi, gangguan afektif bipolar, skizofrenia, kecemasan, demensia, gangguan pemanfaatan zat, kecacatan kemampuan intelektual, dan gangguan perkembangan dan perilaku yang biasanya terjadi dimulai pada masa kanakkanak dan remaja, termasuk autisme" (WHO, 2013). Diagnostic and Statistical Manual of Mental Disorders fifth edition (DSM-V) juga mendefinisikan berbagai jenis penyakit jiwa, termasuk skizofrenia, kecemasan dan gangguan afektif, gangguan makan, dan gangguan kepribadian (American Psychiatric Association, 2013). Tahun 2020, para ahli memerkirakan bahwa $15 \%$ populasi global akan memiliki masalah dengan gangguan jiwa dan antara $1 \%$ sampai $3 \%$ dari mereka menderita gangguan jiwa berat (Harpham, Reichenheim, Oser, Thomas, Hamid, Jaswal, Ludermir, \& Aidoo, 2003). Para penderita gangguan jiwa terkena dampak tidak hanya harus berurusan dengan gejala dan dampak penyakit, tetapi juga dengan stigmatisasi atau diskriminasi terhadap mereka (Kapungwe, Cooper, Mwanza, Mwape, Kakuma, Lund, dan Flisher, 2010). Menurut Departemen Kesehatan RI (2013), prevalensi penderita gangguan jiwa berat di Indonesia adalah 1.7 per 1.000 dan gangguan jiwa ringan adalah sekitar 6\% dari total populasi. Kebanyakan penderita gangguan jiwa parah terdapat di Yogyakarta, Aceh, Sulawesi Selatan, Bali dan Jawa Tengah (Keliat, 2013). Bukti evidence dari seluruh dunia, terutama dari negara berpenghasilan rendah dan menengah, menunjukkan bahwa komplementer tradisional atalternatif biasa digunakan oleh sejumlah besar orang dengan gangguan jiwa (Gureje dkk, 2015).

Pengobatan tradisional dan alternatif populer di seluruh dunia (Russinova, Wewiorski \& Cash, 2002) dan penelitian tentang pemanfaatan praktek alternatif ini juga telah meningkat (Unutzer dkk., 2000).
Praktek tradisional dan alternatif tampaknya untuk mempromosikan proses pemulihan dengan meningkatkan aspek sosial, spiritual dan fungsi diri (Russinova, Wewiorski \& Cash, 2002). Pasien dengan gangguan jiwa mencari obat tradisional sebagai bagian dari regimen pengobatan mereka terutama di negara-negara berkembang karena mereka percaya bahwa penyakit mereka adalah hasil dari kekuatan supranatural. Di Malaysia, keyakinan kekuatan spiritual ini telah menghasilkan pemanfaatan yang lebih besar pada dukun (Razali, Khan dan Hasanah, seperti dikutip dalam Jorm, 2000). Pengobatan tradisional dan alternatif secara resmi diakui dan telah dimasukkan dalam aspek penyedia layanan kesehatan di Indonesia, Cina, Korea dan Vietnam (Gqaleni, Moodley, Kruger, Ntuli, \& McLeod, 2007). Di negara-negara Afrika, para praktisi tradisional dan alternatif telah memainkan peran yang signifikan dalam kesehatan jiwa Afrika sejak Uni Afrika (UA) mendeklarasikan 'the Decade of African Traditional Medicine'pada tahun 2001 (African Union, 2007). Di Afrika, sekitar setengah dari individu mencari perawatan kesehatan formal untuk gangguan jiwa, memilih dukun dan agama sebagai penyedia layanan pertama mereka (Burns \& Tomita, 2015). Di Benua Amerika, pemanfaatan terapi tradisional dan alternatif ini juga meluas. Sebagai contoh, pasienpasien terus menggunakan penyembuhan alternatif, dimana ritual keagamaan pada sekte Pantekosta melibatkan iman dalam penyembuhan dengan doa secara kelompok serta terapi tumpang tangan di Jamaika (James \& Peltzer, 2012). Namun demikian, beberapa ahli berpendapat bahwa pengobatan tradisional dan alternatif tidak memiliki hasil positif bagi mereka yang menggunakannya. Bahkan, menurut Russinova, Wewiorski dan Cash (2002), pengguna pengobatan alternatif melaporkan status kesehatan yang lebih buruk daripada yang lain yang tidak menggunakannya.

Di Indonesia, banyak penderita yang akhirnya datang berobat ke klinik dan rumah sakit telah berkonsultasi satu atau beberapa penyembuh atau pengobat tradisional (Leimena \& Thong 1979). Sejak tahun 2003, pemerintah Indonesia telah mengeluarkan aturan terkait praktek terapi tradisional 
Muhammad Arsyad Subu: Pemanfaatan Terapi Tradisional dan Alternatif

termasuk paranormal dan pengobatan tradisional Cina di Indonesia. Aturan ini dibuat oleh menteri kesehatan republik Indonesia No. 1076/ Menkes / SK / VII / 2003 (Kementerian Kesehatan, 2003). Pengobatan tradisional dan alternatif Indonesia dibagi menjadi empat kategori: penyembuh yang dengan ramuan tradisional seperti jamu atau minuman herbal, makanan, air dan minyak; instrumen tradisional (koin atau kaca); metode tradisional (pijat, akupresur, dll); dan penyembuh yang menggunakan kekuatan gaib (energi atau aura) (Salan \& Maretzki, 1983).

Berdasarkan tinjauan literatur secara intensif didapatkan bahwa masih sedikit informasi dan penelitian terkait pemanfaatan terapi tradisional dan alternatif oleh penderita gangguan jiwa di Indonesia. Studi yang dilakukan oleh Hirokoshi (1980) pada pesantren di Jawa Barat, menemukan bahwa orang-orang dengan gangguan jiwa di bawah bimbingan dan terapi oleh para guru agama. Hasil studi tersebut juga menemukan bahwa para pemimpin agama Islam memainkan peran penting dalam pengobatan penyakit atau gangguan jiwa dengan metode praktek terapi tradisional dan alternatif.

Penelitian ini bertujuan untuk memberikan analisis yang mendalam untuk memahami hubungan antara penyakit atau gangguan jiwa dengan pemanfaatan terapi tradisional dan alternatif. Tujuan lain penelitian ini adalah untuk membantu menginformasikan pemangku kebijakan, tenaga keperawatan dan institusi pelayanan kesehatan jiwa dan masyarakat secara umum di Indonesia tentang pemanfaatan terapi alternatiftradisional diantara penderita gangguan jiwa di Indonesia. Constructivist Grounded Theory (Charmaz, 2006) digunakan untuk memahami penyakit atau gangguan jiwa dan pemanfaatan terapi tradisional dan alternatif di Indonesia.

\section{Metode Penelitian}

Penelitian ini memberikan pemahaman secara substantif tentang pengalaman pemanfaatanm terapi Tradisional dan alternatif di kalangan penderita gangguan jiwa Indonesia dengan menggunakan Constructivist Grounded
Theory (CGT). Constructivist grounded theory diperkenalkan pertama kali oleh Kathy Charmaz dalam bukunya, "Constructing Grounded Theory - A practical guide through qualitative analysis" (Charmaz, 2006). Desain grounded theory Charmaz konsisten dengan epistemologi dan ontologi 'konstruktivisme' yang menempatkan prioritas pada fenomena penelitian dan melihat data dan analisisnya sebagai hal yang dibuat dari pengalaman bersama peneliti dan hubungan dengan partisipan dan sumbersumber data yang lain" (Charmaz 2006). Charmaz mengklaim bahwa disain penelitian ini lebih pada pendekatan objektivis, yang mana peran peneliti adalah untuk menemukan kebenaran yang ada di dalam objek penelitian dan meminimalisasi 'kekuatan (power) (Charmaz, 2006). Dengan demikian data diasumsikan sebagai fakta-fakta objektif dan sudah ada di dunia dan melalui pendekatan objektivis untuk ditemukan oleh peneliti dan selanjutnya untuk menentukan teori atau pemahaman secara substantif tentang faktafakta tersebut (Charmaz, 2006).

Penelitian ini dilakukan di salah satu institusi pelayanan kesehatan (rumah sakit jiwa) yang terletak di Provinsi Jawa Barat di Indonesia. Rumah sakit ini adalah salah satu pelayan kesehatan jiwa terbesar di Indonesia. Partisipan penelitian yang direkrut adalah pasien laki-laki dan perempuan serta perawat laki laki dan perempuan yang bekerja di rumah sakit. Sebanyak 30 partisipan (15 pasien dan 15 perawat) direkrut, yang menurut Charmaz (2006), lebih dari cukup untuk memastikan kejenuhan data. Para partisipan hanya orang dewasa warga negara Indonesia, memiliki kemampuan untuk membaca dan menulis, berusia18 tahun atau lebih. Pasien yang menjadi partisipan dalam penelitian ini adalah mereka yang memiliki gangguan jiwa dan pernah memanfaatkan terapi tradisional dan alternatif.

Pengumpulan data dalam penelitian ini menggunakan 4 (empat) metode. Salah satu metode pengumpulan data tersebut adalah wawancara semi-terstruktur. Semua wawancara direkam dengan menggunakan digital audio (audio-taped). Metode pengumpulan data kedua adalah dokumen review yang bertujuan sebagai triangulasi data yang berfungsi untuk meningkatkan 
Muhammad Arsyad Subu: Pemanfaatan Terapi Tradisional dan Alternatif

probabilitas penelitian dan bahwa interpretasi data adalah kredibel (Lincoln \& Guba, 1985). Dokumen yang dikumpulkan dalam bentuk fotokopi dan elektronik yang meliputi laporan dan log book perawat, pre dan post konferensi, newsletter, visi, misi dan moto rumah sakit dan bahan dan laporan-laporan lainnya. Memo adalah cara untuk mendokumentasikan pengalaman dan menciptakan laporan di atas kertas secara nyata yang menjelaskan proses berpikir peneliti. Catatan lapangan digunakan untuk mencatat observasi dan refleksi data, sebagai bagian dari pendekatan refleksif dengan proses analisis data (Charmaz, 2006). Semua partisipan menandatangani informed consent sebagai bentuk kesediaan untuk berpartisipasi dalam penelitian ini.

Penelitian ini, metode analisis data Paille (1994) yang mencerminkan prinsip dasar metode analisis data oleh Charmaz (2006), digunakan untuk mengelola dan menganalisa data. Paille (1994) analisis data ini meliputi: kodifikasi, kategorisasi, menghubungkan kategori, integrasi, konseptualisasi, dan teorisasi. Heath dan Cowley (2004) mengusulkan tiga tahapan utama dalam analisis data grounded theory: 'coding awal, tahap menengah, dan pengembangan akhir'. Berdasarkan tahapan ini, Charmaz (2006) grounded theory dimulai dengan koding awal, koding terfokus (tahap menengah), dan pengkodean teori (pengembangan akhir). Data analisis Paille (1994) juga dapat dibagi menjadi tiga tahap: kodifikasi dan kategorisasi (koding awal), menghubungkan kategori dan integrasi (tahap menengah), konseptualisasi dan teorisasi (pengembangan akhir).

Tahap kodifikasi dimulai dengan mengatur kata-kata, persepsi dan pengalaman dalam kode secara terorganisir (proses pembentukan kode). Tujuan tahap kodifikasi adalah memberi nama, mengungkap, meringkas dan label, baris demi baris, dari data transkripsi yang diperoleh dari wawancara. Kodifikasi membantu mengidentifikasi adanya tumpang tindih antara kode awal dan pembentukan kategori. Tahap kategorisasi adalah untuk menggambarkan fenomena umum atau peristiwa yang muncul dari data dan kemudian dibuat daftar kategori yang teridentifikasi pada tahap kodifikasi. Tahap ini adalah untuk menentukan kategori dengan mengidentifikasi variasi dalam data dapat dijelaskan dengan kategori lain. Dalam tahap menghubungkan kategori, Paille (1994) memberikan tiga pendekatan: (1) pendekatan empiris, (2) pendekatan teoritis, dan (3) pendekatan spekulatif. Pendekatan empiris didasarkan pada perbandingan dari masingmasing kategori dan fenomena. Pendekatan teoritis membantu untuk mengidentifikasi hubungan antara kategori. Pendekatan spekulatif adalah berasal dari pengalaman peneliti untuk berkontribusi pada proses analisis. Tahap integrasi menentukan fenomena-feomena yang telah diamati secara empiris. Dengan mengintegrasikan hubungan antara kategori, peneliti mengidentifikasi kongruensi tertentu yang muncul antara data kasar dan arah penelitian yang diambil selama analisis. Tahap konseptualisasi adalah proses pengembangan dan klarifikasi konsep- konsep dan ide-ide yang muncul dan untuk menjelaskan konsep dengan kata-kata dan untuk memberikan definisi konseptual secara verbal. Proses ini memungkinkan peneliti untuk memahami fenomena penelitian dan kompleksitasnya. Akhirnya, tahap teorisasi merupakan proses konstruksi untuk menguatkan teori atau pemahaman susbstantif. Menurut Paille (1994), teori merupakan produk dari proses secara ketat yang dibuat setelah peneliti mengikuti setiap langkah-langkah analisis. Namun demikian, menurut Charmaz (2006), tidak semua penelitian grounded theory menghasilkan teori tapi pemahaman yang mendalam dan substantif merupakan hasil akhir dari sebuah penelitian dengan grounded theory.

\section{Hasil Penelitian}

Kategori 1: Kerasukan (Setan, Roh atau Jin) Beberapa budaya di Indonesia masih mempercayai konsep kerasukan, dimana mereka percaya bahwa penyakit jiwa disebabkan oleh 'setan, roh atau jin jahat'. Menurut salah seorang partisipan perawat, masyarakat masih dipengaruhi juga oleh kepercayaan tentang masa lalu; jika seseorang menderita penyakit jiwa, itu karena ia kerasukan setan atau roh.

Benar iya iya ... pasien dan keluarga menggunakan terapi atau pengobatan alternatif pada orang-orang pintar yang 
Muhammad Arsyad Subu: Pemanfaatan Terapi Tradisional dan Alternatif

banyak di luar sana karena mereka menganggap sakit jiwa akibat disambar atau dipengaruhi.... atau kerasukan setan, dikuasai oleh jin atau roh dan sebagainya, ... itu yang saya ketahui dari pasien. Jadi gangguan jiwa dikaitkan dengan setan, jin atau mahluk halus (Pr2).

Kategori 2: Penyakit Dosa

Orang orang juga masih berasumsi bahwa penyakit atau gangguan jiwa disebabkan oleh dosa-dosa penderita sendiri atau dosa keluarganya. Oleh karena itu, merupakan hal yang menjatuhkan martabat atau memalukan bagi keluarga jika seseorang menderita gangguan jiwa.

Masyarakat kita berbeda beda. Juga, pendidikan mereka berbeda beda. Umumnya mereka mengasumsikan bahwa penyakit gangguan jiwa adalah akibat dari dosa. Apa namanya? Dosa.....akibat perilaku masa lalu... masa lalu pasien. Bisa juga masa lalu keluarganya, bisa ibu atau bapaknya atau dosa kakek atau neneknya. Bisa juga karena keturunan ... pasti ... karena penyakit akibat dosa ini, mereka dianggap orang orang yang berdosa (Pr6).

Kategori 3: Berobat ke tradisional dulu baru akhirnya ke rumah sakit jiwa

Menurut beberapa partisipan, umumnya penderita gangguan jiwa awalnya dibawa ke orang orang pintar yang praktek terapi tradisional dan alternatif. Nampaknya pengobatan Tradisional dan alternatif ini sering merupakan pilihan pertaman oleh pasien, keluarga dan masyarakat. Banyak anggota keluarga mengingkari keluarganya menderita gangguan jiwa dan beranggapan bahwa penderita kerasukan setan. Oleh karena itu penderita dibawa ke orang orang pintar.

Umumnya pasien pergi kemana-mana mencari pengobatan alternatifkarena mereka menganggap bahwa mereka kemasukan setan, jin dan mereka sakit dan stress karena itu. Dengan demikian keluarga berpikir tidak perlu ke rumah sakit jiwa. Mereka pergi ke dukun dulu, ke pastor dulu... ke tempat tempat ini dulu. Kemana mana dulu ... ya, umumnya, jika memungkinkan mereka tidak ke rumah sakit untuk tritmen dulu. Umumnya mereka ke rumah sakit sebagai pilihan terakhir. Beberapa keluarga mengatakan “ kami sudah habis-habisan. Semuanya telah habis (Pr11).

Ada beberapa jenis pengobatan tradisonal atau alternatif di masyarakat Indonesia. Mulai dari “ orang pintar", termasuk dukun, pemimpin agama atau guru agama Islam (kiyai atau ulama), paranormal, pendeta, dan pengobatan tradisional Cina. Dalam praktek, orang pintar menggunakan herbal, jampi, mantra, benda mati, komunikasi atau bimbingan rohani, dan doa sebagai bentuk penyembuhan. Salah satu pasien bersikeras tidak percaya pada dukun tapi ia tidak punya pilihan selain untuk menyetujui keinginan orang tuanya. Namun, setelah pengobatan dengan dukun tersebut, ia menyatakan bahwa ia tidak memiliki hasil yang positif, dia tidak sembuh.

.... Mereka membawa saya ke dukun. Semua orang gila harus pergi ke dukun. Ya, saya juga pegi ke dukun .... ayah saya juga, demi kesembuhan saya. Ayah saya bingung, kehabisan akal. Kami pergi ke Bengkulu dan saya nginap di rumah keluarga saya. Di dukun tersebut, ada ayam yang siap dipotong. Voodoo seperti ini juga. Apapun yang diminta oleh dukun, kami ikuti. Tapi setelah itu, tidak ada perubahan. Dukun itu dari sana ... pakaiannya hitam-hitam dan dia jarang mandi. Ini benar benar terjadi... banyakjenis dukun-dukun tersebut. Beberapa memelihara tuyul dan mereka miskin-miskin. Mereka (dukun) membuat orang kaya tapi rumah mereka gubuk-gubuk. Di tempat dukun ini saya didoakan air. Seseorang telah mengirim santet kepada saya. Ada juga jeruk dibuka..... dan katanya (dukun) seorang teman saya di sekolah ingin menguna-gunai saya..... Sebenarnya, saya tidak percaya tapi karena kondisi saya, saya ingin benar-benar sembuh, olehnya itu saya ikuti saja. Setelah sampai di rumah dari Bengkulu, tidak ada hasilnya. Seperti biasa, saya stres lagi (Ps 10).

Menurut pasien partisipan, paranormal merupakan salah satu pilihan pengobatan alternatif untuk penderita. Nampaknya, paranormal mengkhususkan diri dalam pengobatan yang umumnya pada masalahmasalah spesifik pasien dengan pengobatan dengan doa. Pasien merasa bahwa 
Muhammad Arsyad Subu: Pemanfaatan Terapi Tradisional dan Alternatif

mengunjungi paranormal hanya membuat pengobatan dengan profesi kesehatan kemudian menjadi lebih sulit.

[Paranormal] iya di paranormal..... selanjutnya mereka ke tempat paranormal. Di tempat paranormal, orang sakit jiwa didoakan, diberi terapi mantra. Mereka (penderita) tidak sadar, pengobatan dan mantra. Banyak orang yang benar benar hilang ingatan. Setelah itu, dokter susah menyembuhkan mereka.... (Ps7).

Pengobatan tradisional Cina (Traditional Chinese Medicine), termasuk berbagai bentuk pengobatan dengan herbal, akupuntur, pijat dan terapi diet adalah salah satu pilihan para penderita gangguan jiwa. Salah seorang pasien menggambarkan pengalamannya.

Saya pernah di pengobatan tradisional Cina juga. Seorang pengobat Cina disitu .... namanya KKL. Saya minum pil Cina. Ya saya pernah dari situ. Selanjutnya, orang Cina itu bilang wu wu wu wu wu untuk mengeluarkan setan, jin dan roh, energi negatif saya sehingga saya memberinya uang sebagai pengobatan. Setan itu (tertawa)... jin itu... (tidak jelas). Setan .... puoooooohhh pergi jauh. Ya, itu benar benar nyata ... seperti itu. Ketika saya teriak keras...... setan itu pergi, seperti itu (Ps3).

\section{Kategori 4: Perilaku Kekerasan}

Banyak penderita gangguan jiwa, keluarga dan anggota masyarakat di Indonesia yang mencari bantuan dari pengobatan Tradisional dan alternatif mengalami kekerasan dari para terapis ini. Banyak yang terpaksa berhenti mengonsumsi obat mereka dan diharuskan untuk minum obat yang diberikan oleh para penyembuh tersebut.

Oh iya ... jika pasien memiliki pengobatan pada orang-orang pintar, apa yang saya tahu dan saya lihat dengan pasien, biasanya mereka tidak diperbolehkan untuk mimum obat ... Ya, mereka tidak diperbolehkan untuk minum obat-obatan medis. Mereka minum air putih, zikir atau doa wirid .... (N6).

Pasien lainnya mengalami terapi dimana terapis alternatif melakukan abuse seperti menenggelamkan, mencambuk, atau dimandikan secara paksa.
Ya, saya disana (tradisional dan alternatif) selama satu setengah bulan. Disana, saya dimandikan di tengah malam. Dukun ingin menggunakan ilmu sihir, [tidak jelas], ia memukuli saya. Saya dimandikan jam satu malam. Saya tidak tidur. Badan saya kocok kocok mirip dengan kambing. Saya ada di sana selama satu setengah bulan, namun saya tidak sehat, saya tidak lebih baik (Ps2).

Beberapa pasien dipaksa untuk makan makanan yang aneh, seperti makan telur mentah dan cabai, atau harus makan daun daunan. Tipe lain dari perlakuan tidak manusiawi tapi populer yang dilakukan oleh dukun adalah pijat keras atau penyek-penyak yang dilakukan pada seluruh tubuh. Tujuan dari pijat keras ini juga untuk melepaskan setan dari tubuh pasien.

Saya diperlakukan seperti ini (memberi contoh) ...... kepala saya diperlakukan seperti ini [menunjukkan],... Wah ... panas ... panas, sangat panas. Kadang-kadang dukun tersebut melakukan kekerasan ... dia menggebrak meja ... brukkkkk, seperti itu ... Kemudian, iblis atau setan dalam tubuh saya keluar," katanya. Mereka [dukun] berpikir bahwa ada setan dalam tubuh saya ... Ya, mereka melakukan begitu. saudara-saudara saya berpikir begitu juga.....(Ps3).

Kategori 5: Ketakutan dengan Pengobatan Pasien sering merasa takut terkait dengan tritmen dan pengobatan mereka, terutama abuse akibat dari pengobatan alternatif atau obat-obatan tradisional. Satu pasien partisipan yang telah dibawa ke dukun mengalami ketakutan.

$Y a$, ummm ya ... itu salah. Di $N$ [kabupaten di Jawa Timur], saya pernah disana, tiga bulan; hal itu menakutkan. Saya berada di daerah terpencil di Jawa, dan tempat itu sangat gelap. Saya berkewajiban untuk bertemu MA [dukun] ... saya dalam satu ruangan. Saya takut sekali. MA (dukun) ada di sana. Dia adalah mantan penderita jiwa juga. Dia mengatakan: "Ini adalah penyakit gila, ini adalah psikopat, " katanya. Aku ingin lari, melarikan diri. Aku benar-benar takut melihat kapaknya. Saya sangat stres, itu adalah pengobatan aneh (Ps 3). 
Muhammad Arsyad Subu: Pemanfaatan Terapi Tradisional dan Alternatif

\section{Pembahasan}

Pengobatan tradisional dan alternatif di Indonesia meliputi unsur-unsur asli budaya Melayu (proto-Malay) yang akhirnya dipengaruhi oleh agama Hindu, Muslim, beberapa aspek dari budaya Cina, dan Kristen dan semua ini merupakan gabungan dan diserap oleh strata budaya Indonesia (Hawari, 2001 \& Salan \& Maretzki, 1983). Menurut Maramis (2007), terapi pelayanan kesehatan penderita gangguan jiwa di Indonesia belum optimal. Kurang dari 1\% dari total anggaran kesehatan di Indonesia diarahkan layanan kesehatan jiwa (terendah di Asia), dan Indonesia adalah salah satu negara di dunia yang memiliki rasio terendah psikiater per kapita (Irmansyah, 2010). Menurut Minas dan Diatri (2008), kualitas pelayanan kesehatan jiwa di rumah sakit juga belum optimal dan ideal di Indonesia sehingga keluarga cenderung membawa penderita ke dukun, pemimpin agama, atau yang terkait dengan jenis lain dari pengobatan tradisional dan alternatif. Dalam konteks negara-negara berpenghasilan rendah dan menengah, proporsi cukup besar dari individu mencari pelayanan kesehatan untuk gangguan jiwa adalah berkonsultasi pada berbagai pengobatan alternatif seperti dukun dan ahli agama (Burns \& Tomita, 2015).

Hasil penelitian membuktikan bahwa salah satu tempat untuk pengobatan alternatif penderita gangguan jiwa adalah di Pesantren atau Pondok Pesantren. Pesantren telah memainkan peran utama dalam memberikan penyembuhan atau pengobatan berdasarkan nilai-nilai Islam di pesantren. Pesantren yang dipimpin oleh guru Islam atau pemimpin agama yang dikenal sebagai 'Kiyai' atau 'ulama' (Nelson, 1999). "Pesantren adalah istilah yang berasal dari akar kata santri atau siswa pe-santri-an atau tempat santri" (Lukens-Bull, 2005). Dhofier (1980) menyebutkan bahwa Indonesia mengacu pada kyai sebagai ulama, yang merupakan bentuk jamak dari 'orang alim' kata dari bahasa Arab (orang yang berpengetahuan). "Seorang kyai memiliki posisi dan otoritas karena orang akan mendengarkan apa yang dia katakan itu" (Platvoet \& van der Toorn, 1995). Banyak warga yang beragama islam di Indonesia menganggap kiyai memiliki peringkat lebih tinggi dari ustadz karena kiyai yang menjalankan pesantren sendiri dan kadang memiliki kemampuan mistis (Lukens-Bull, 2005). Selain itu, pendeta agama kristen juga adalah bentuk lain dari orang pintar sebagai terapis di Indonesia. Seorang pendeta memberikan dukungan pastoral (spiritual) dan emosional untuk tenaga pelayanan di sekolah-sekolah atau universitas, penjara dan pelayanan kesehatan (Hewson, 2012 \& Norman, 2004). Pendeta Kristen adalah bentuk 'pelayanan pastoral' (Nelson, 1999).

Di Indonesia, banyak orang masih selalu percaya pada hal-hal supranatural dan kerasukan seperti setan, hantu, roh dan sihir sehingga penderita gangguan jiwa sering dibawa ke dukun. Beberapa teori telah mencoba untuk menjelaskan akar penyebab gangguan jiwa dan salah satu teori ini berhubungan dengan kerasukan setan. Penduduk Kenya di benua Afrika banyak yang masih percaya gangguan jiwa berkaitan dengan kerasukan setan sehingga membutuhkan pengobatan dukun atau para imam (Musyimi, Mutiso, Nandoya, \& Ndetei, 2016).

Beberapa budaya dan agama, termasuk Islam, Kristen, Budha, Voodoo Haiti, dan Hindu mempertahankan semacam keyakinan pada kemampuan setan atau roh untuk mengambil kendali daalam tubuh manusia. Banyak orang Kristen juga percaya bahwa kerasukan setan berasal dari Iblis atau setan. Dalam banyak sistem kepercayaan Kristen, Setan dan iblis adalah malaikat yang jatuh atau 'fallen angel' (MacKenzie, 1999). Di Jamaika, pasien juga terus menggunakan penyembuh alternatif, di mana ritual keagamaan di sekte Pantekosta melibatkan iman penyembuh dengan doa kelompok dan dengan metode tumpang tangan (James \& Peltzer, 2012).

Menurut Nuhriawangsa (2011), para pasien dan penderita gangguan jiwa dianggap mistik yaitu suatu keadaan terkait kemasukan setan. Cara pengobatan dijalankan dengan secara majik-mistik dengan maksud mengusir setan dari dalam tubuh pasien tersebut yang biasanya dikerjakan oleh dukun atau orangorang yang berkecimpung dalam soal-soal 
Muhammad Arsyad Subu: Pemanfaatan Terapi Tradisional dan Alternatif

kebatinan. Dukun dan pengobat tradisional lain merupakan cara yang mudah dan tersedia bagi penduduk Indonesia yang menderita gangguan jiwa di Indonesia (Depkes, 2006). Dukun merupakan penyembuh tradisional, media adat dan tradisi. Umumnya mereka adalah para ahli sihir dan ahli ilmu hitam. Seorang dukun diyakini dapat berkomunikasi dengan roh-roh jahat dan roh baik hati. Juga, paranormal juga dipilih sebagai penyembuh terapi alternatif oleh pasien, keluarga dan anggota masyarakat.

Rabeyron \& Watt (2010) menyatakan bahwa korelasi yang signifikan ditemukan antara pengalaman paranormal dengan mental, trauma psikologis dan peristiwa kehidupan yang negatif. Hasil keseluruhan yang tidak signifikan untuk tugas psi dan tidak ada hubungan yang signifikan yang ditemukan antara variabel psikologis dan hasil psi terkait paranormal. Temuan ini menunjukkan bahwa batas mental tidak berhubungan dengan pengalaman paranormal dan bahwa pengalaman paranormal terjadi terutama sering setelah peristiwa kehidupan yang negatif. Namun demikian, sangat sedikit literatur terbaru membahas khusus tentang prevalensi dari keyakinan terkait paranormal atau interpretasi kejiwaan dari pengalaman subjektif paranormal (Dein, 2012). Tidak ada hasil eksperimen penelitian yang mendapatkan penerimaan secara luas dalam komunitas ilmiah terkait bukti yang valid dari terapi paranormal (Oling-Smee, 2007). Banyak orang yang menderita gangguan jiwa dan keluarga mereka juga menggunakan pengobatan tradisional Cina (Traditional Chinese Medicine atau TCM) sebagai piliha. Pengobatan ini digunakan secara luas di Cina dan di negara-negara Barat. Praktek TCM dalam masyarakat Indonesia termasuk berbagai bentuk jamu, akupunktur, pijat, dan terapi diet (Shang, Huwiler, Nartey, Jüni, \& Egger, 2007: Subu, 2015). Namun demikian, efektivitas obat herbal Cina masih kurang diteliti dan didokumentasikan di Indonesia.

Penelitian ini juga membuktikan bahwa pengobatan tradisional dan alternatif seringkali bisa brutal atau dengan perilaku kekerasan terhadap penderita gangguan jiwa. Beberapa pasien telah mengalami kekerasan fisik dalam bentuk diceburkan kedalam air, pijatan keras atau dipaksa untuk makan makanan yang tidak diinginkan. Beberapa penderita dibiarkan sendiri di hutan, sehingga banyak pasien merasa bahwa mereka diperlakukan seperti binatang. WHO (2001) menunjukkan bahwa banyak kali pasien diabaikan, terisolasi, atau diobati dengan ritual alternatif daripada dengan terapi obat yang tepat. Orang dengan gangguan jiwa yang memiliki kemampuan dan sumber daya yang kurang, sehingga mengalami mengalami kekejaman dan mereka sering dieksploitasi (Goffman, 1963). Banyak orang dengan gangguan jiwa di Indonesia yang mencari bantuan dari terapis untuk pengobatan tradisional dan alternatif ini diperlakukan secara kasar atau mereka mengalami perilaku kekerasan oleh terapis mereka. Hal ini telah mengakibatkan ketakutan dan pengalaman traumatis yang dirasakan oleh para penderita gangguan jiwa yang telah berobat ke terapi tradisional dan alternatif (Subu, 2015).

\section{Simpulan}

Hasil penelitian ini menunjukkan bahwa pengobatan tradisional dan alternatif memainkan peran penting dalam sistim kesehatan Indonesia untuk memenuhi kebutuhan tentang pengobatan kesehatanjiwa. Pengobatan ini adalah pilihan pertama pasien jiwa dan keluarga mereka. Sebuah penelitian lain di Indonesia menunjukkan bahwa kebanyakan pasien jiwa telah menggunakan metode penyembuh tradisional dan alternatif sebelum pergi ke fasilitas kesehatan (Hawari, 2001). Hasil penelitian ini juga menunjukkan beberapa jenis pengobatan tradisional dan alternatif atau 'orang pintar', yang ada di masyarakat Indonesia termasuk ulama atau guru agama Islam (Kyai atau ulama), paranormal, pendeta, pengobatan Cina dan dukun. Hasil penelitian memberikan bahan dan informasi yang berguna untuk penelitian yang akan datang tentang penderita gangguan jiwa dan kaitannya dengan pemanfaatan terapi tradisional dan alternatif di Indonesia. Penelitian lanjut diperlukan untuk melihat efektifitas terapi tradisional dan alternatif ini karena metode terapi ini masih kurang diteliti dan didokumentasikan di Indonesia. 
Muhammad Arsyad Subu: Pemanfaatan Terapi Tradisional dan Alternatif

Selain itu, penelitian ini belum terfokus pada gangguan jiwa dan pemanfaatan terapi alternatif dari perspektif keluarga, masyarakat dan pemerintah. Penelitian diperlukan untuk melihat bagaimana perpektif keluarga sebagai partisipan dalam kaitannya dengan terapi tradisional dan alternatif terkait penderita gangguan jiwa. Penelitian lebih lanjut juga perlu dilakukan untuk memahami sikap masyarakat dan staf lembaga pemerintahan sebagai partisipan penelitian terkait dengan pengobatan tradisional dan alternatif ini dari perspektif mereka. Penelitian juga diperlukan untuk memahami perspektifterapis tradisional dan alternatif dalam rangka meningkatkan pengetahuan mereka dan langkah-langkah tritmen tanpa kekerasan pada penderita gangguan jiwa. Pemanfaatan lokasi penelitian pada institusi kesehatan jiwa lain atau lokasi lain di masyarakat yang berbeda mungkin akan dapat mendapatkan data dan hasil yang kemungkinan berbeda. Akhirnya, penelitian dengan pendekatan kuantitatif diperlukan untuk dapat menggeneralisasi hasil penelitian tentang faktor-faktor yang mempengaruhi pemanfaaatan terapi tradisional dan alternatif oleh penderita gangguan jiwa di Indonesia.

\section{Daftar Pustaka}

American Psychiatric Association (2013). Diagnostic and Statistical Manual on Mental Disorders, Fifth Edition (DSM-V). Washington, DC: American Psychiatric Press.

African Union. (2007). African Health Strategy 2007-2015: Third Session of the African Union Conference of Ministers of Health. Johannesburg South Africa: African Union.

Burns, J.K, \& Tomita, A.( 2015). Traditional and religious healers in the pathway to care for people with jiwa disorders in Africa: a systematic review and meta-analysis. Social Psychiatry and Psychiatric Epidemiology, 50(6), 867-77.

Charmaz, K. (2006). Constructing Grounded Theory. A Practical Guide Through Qualitative Analysis. London: Sage
Publications.

Dein, S. (2012). Mental Health and the Paranormal. International Journal of Transpersonal Studies, 31(1), 61-74.

Departemen Kesehatan Republik Indonesia (2006). Final Report. Development of National Policy and Strategy for Mental Hospital. Direktorat Kesehatan Jiwa. Kementerian Kesehatan Republik Indonesia.

Departemen Kesehatan Republik Indonesia (2013). Riset Kesehatan Dasar. Riskesdas 2013. Jakarta: Badan Penelitian dan Pengembangan Kesehatan Depkes RI.

Dhofier, Z. (1980). The Pesantren Tradition: A Study of the Role of the Kyai in the Maintenance of the Traditional Ideology of Islam in Java. Program for Southeast Asian Studies Monograph Series.Tempe, AZ: Arizona State University.

Gqaleni, N., Moodley, I., Kruger, H., Ntuli, A., \& McLeod, H. (2007). Traditional and Complementary Medicine. South Africa Health Review, 12, 175-188.

Goffman, E. (1963). Stigma: Notes on the Management of Spoiled Identity. New Jersey: Prentice-Hall; Englewood Cliffs.

Gureje, O; Nortje, G., Makanjuola, V., Oladeji, B., Soraya Seedat, S., \& Rachel Jenkins (2015). The role of global traditional and complementary systems of medicine in treating jiwa health problems. Lancet Psychiatry, 2(2), 168-177.

Harpham, T., Reichenheim, M., Oser, R., Thomas, E., Hamid, N., Jaswal, S., Ludermir, A., \& Aidoo, M. (2003). Measuring health in cost effective manner. Health Policy and Planning, 18(3), 344. doi: 10.1093/heapol/ czg041.

Hawari, D. (2001). Pendekatan Holistik Pada Gangguan Jiwa Skizofrenia. Jakarta Indonesia: Gaya Baru.

Heath, H., \& Cowley, S. (2004). 'Developing a Grounded Theory Approach: A Comparison 
Muhammad Arsyad Subu: Pemanfaatan Terapi Tradisional dan Alternatif

of Glaser and Strauss. International Journal of Nursing Studies, 41(2), 141-150.

Hewson, C. (2012). Multifaith Spaces: Management. University of Manchester. Diunduh dari: http://www.multi-faith-spaces. org.

Hirokoshi, H. (1980). Asrama: An Islamic Psychiatric Institution in West Java. Social Science and Medicine, 14B, 157-165. doi:10.1016/0160-7987(80)90005-8.

Irmansyah (2010). Kesehatan Jiwa di Indonesia. Bina Kesehatan Jiwa Kementerian Kesehatan RI. Jakarta.

James, C.C, \& Peltzer, K. (2012). Traditional and alternative therapy for mental illness in Jamaica: patients' conceptions and practitioners' attitudes. African Journal of Traditional and Complement Alternative Medicine, 9(1), 94-104.

Jorm, F.A. (2000). Mental health literacy. Public knowledge and beliefs about mental disorders. British Journal of Psychiatry, 177, 296-401.

Kapungwe, A., Cooper, S., Mwanza, J., Mwape, Sikwese, L.A., Kakuma, Lund, R.C., \& Flisher, A.J. (2010). Mental illness stigma and discrimination in Zambia. African Journal of Psychiatry, 13, 192-203.

Keliat, B.A. (2013). Kontribusi Keperawatan Kesehatan Jiwa dalam Meningkatkan Pelayanan Kesehatan Jiwa di Indonesia. Pidato Pengukuhan Profesor Universitas Indonesia. Depok Jawa Barat: Universitas Indonesia (UI).

Kementerian Kesehatan Republik Indonesia. (2003). Keputusan Menteri Kesehatan Republik Indonesia nomor 1076/Menkes/ SK/VII/2003 Tentang Penyelenggaraan Pengobatan Tradisional. Jakarta: Ministry of Health of Indonesia.

Lincoln, Y. \& Guba, E. (1985). Naturalistic inquiry. Newbury Park, CA: Sage.

Lukens-Bull, R. (2005). A Peaceful Jihad
-Negotiating Identity and Modernity in Muslim Java. Palgrave Macmillan.

MacKenzie, N.V. (1999). An Exorcist tells his Story by Fr. Gabriele Amorth (versi terjemahan). San Francisco: Ignatius Press.

Maramis, W.E. (2007). Ilmu kedokteran jiwa. Surabaya Indonesia: Airlangga Press.

Minas, H \& Diatri, H. (2008). Pasung: Physical restraint and confinement of the mentally ill in the community. International Journal of Mental Health Systems, 2(8).

Nelson, G. (1999). Pastoral reflection. In Solari-Twadell, P.A. and Mc Dermot, M.A. (Eds), Parish Nursing: Promoting whole person health within faith communities (pp. 161-167). Thousand Oaks, CA: Sage Publications.

Norman, J. (2004). At The Heart of Education: School Chaplaincy and Pastoral Care. Dublin: Veritas.

Nuhriawangsa, I. (2011). Pengobatan praktis terhadap pasien gangguan iiwa. Diambil dari: http://nuhriawangsa.blogspot.co.id/2011/08/ pengobatan-praktis-terhadap-pasien.html.

Musyimi, C.W., Mutiso, V.N., Nandoya, E.S., \& Ndetei, D. M. (2016). Forming a joint dialogue among faith healers, traditional healers and formal health workers in jiwa health in a Kenyan setting: towards common grounds. Journal of Ethnobiology and Ethnomedicine; 12(1), 4.

Oling-Smee, L. (2007). The Lab that Asked the Wrong Questions. Nature, 446 (7131), 10-11. doi:10.1038/446010a.

Paille, P. (1994). L'analyse Par Théorisation Ancrée, Cahiers de Recherche Sociologique, 23,147-181.

Platvoet, J. \& van der Toorn, K. (1995). Pluralism and Identity: Studies in Ritual Behaviour. Leiden: Brill Academic.

Rabeyron, T, \& Watt, C. (2010). Paranormal experiences, mental health and mental 
Muhammad Arsyad Subu: Pemanfaatan Terapi Tradisional dan Alternatif

boundaries, and psi. Personality and Individual Differences, 48(4), 487-492.

Russinova, Z., Wewiorski, N.J., and Cash, D. (2002). Use of Alternative Health Care Practices by Persons with Serious Mental Illness: Perceived Benefits. American Journal of Public Health, 92(10), 1600-1603.

Salan, R. \& Maretzki, T. (1983). MentalHealth-Services and Traditional Healing in Indonesia-are the Roles Compatible. Culture Medicine and Psychiatry, 7(4), 377-412.

Shang, A., Huwiler, K., Nartey, L., Jüni, P., \& Egger, M. (2007). Placebo-Controlled Trials of Chinese Herbal Medicine and Conventional Medicine Comparative Study. International Journal of Epidemiology, 36 (5), 1086-1092.
Subu, M.A. (2015). Persistent Taboo: Understanding Mental Illness and Stigma among Indonesian Adults Through Grounded Theory. Doctoral dissertastion School of Nursing University of Ottawa Canada.

Unutzer, J., Klap, R., Sturm, R., Young, A. S., Marmon, T., Shatkin, J., dkk. (2000). Mental disorders and the use of alternative medicine: Results from a national survey. American Journal of Psychiatry, 157(11), 1851-1857.

World Health Organization (2001). The World Health Report 2001 - Mental Health: New Understanding, New Hope. Geneva: World Health Organization.

World Health Organization (2013). Mental Health Action Plan 2013-2020. Geneva, Switzerland: World Health Organization. 